\title{
PENGARUH MODEL PEMBELAJARAN DAN GAYA BERPIKIR SEKUENSIAL TERHADAP HASIL BELAJAR BAHASA JERMAN SISWA
}

\author{
Rosmalia Devi', Harun Sitompul ${ }^{2}$ Evi Eviyanti ${ }^{3}$ \\ ${ }^{1}$ Sekolah Menengah Atas Negeri 13 Medan, Sumatera Utara \\ ${ }^{2,3}$ Program Pascasarjana Universitas Negeri Medan \\ ${ }^{1}$ rosmaladevi@gmail.com; ${ }^{2}$ prof_runsit@yahoo.co.id
}

\begin{abstract}
Abstrak: Tujuan penelitian quasi experiment ini adalah untuk mengetahui: (1) hasil belajar Bahasa Jerman siswa yang dibelajarkan dengan model pembelajaran Kooperatif Tipe Jigsaw lebih tinggi dibandingkan yang dibelajarkan dengan model pembelajaran Langsung, (2) perbedaan hasil belajar Bahasa Jerman siswa yang memiliki gaya berpikir sekuensial Abstrak dan gaya berpikir sekuensial Konkrit, dan (3) interaksi antara model pembelajaran dan gaya berpikir sekuensial terhadap hasil belajar Bahasa Jerman siswa. Metode penelitian yang digunakan adalah quasi eksperimen dengan desain penelitian faktorial $2 x 2$. Teknik analisis data yang digunakan ANAVA dua jalur. Hasil Penelitian menunjukkan bahwa (1) hasil belajar Bahasa Jerman siswa yang dibelajarkan dengan model pembelajaran Kooperatif Tipe Jigsaw lebih tinggi dibandingkan dengan hasil belajar Bahasa Jerman siswa yang dibelajarkan dengan model pembelajaran Langsung, $\left(F_{\text {hitung }}=36,00\right)$, (2) terdapat perbedaan hasil belajar Bahasa Jerman siswa yang memiliki gaya berpikir sekuensial Abstrak dan gaya berpikir sekuensial Konkrit $\left(F_{\text {hitung }}=9,41\right)$, dan (3) terdapat interaksi antara model pembelajaran dan gaya berpikir sekuensial $\left(F_{\text {hitung }}=\right.$ $46,79)$.
\end{abstract}

Kata Kunci: model pembelajaran, gaya berpikir sekuensial, hasil belajar bahasa jerman

Abstract: The objectives of this quasi experimental research were to discover whether: (1) the students' achievement in German taught by using Jigsaw Cooperative Type of Instructional Model was higher than the students' learning achievement in German taught by using Direct Instructional Model, (2) the difference between students' learning achievement in German with Abstract Sequential Thinking Style and Concrete Sequential Thinking Style, and (3) the interaction between Instructional Model and Sequential Thinking Style on students' learning achievement in German. The instrument used to collect the data were a multiple choice test with 35 items, at was a factorial $2 \times 2$ design. The data were analysed using a two way ANOVA. The research results show that: (1) the students' learning achievement in German taught by using Jigsaw Cooperative Type Instructional Model was higher than students' learning achievement taught by using Direct Instructional Model $\left(F_{\text {count }}=36.00\right)$, (2) there was a difference between students' learning achievement in German with Abstract Sequential Thinking Style and Concrete Sequential Thinking Style $\left(F_{\text {count }}=9.41\right)$, and (3) there was an interaction between Instructional Model and Sequential Thinking Style $\left(F_{\text {count }}=46.79\right)$.

Keywords: learning model, sequential thinking style, German learning outcomes

\section{PENDAHULUAN}

Pembelajaran bahasa Asing di Indonesia sudah dimasukkan ke dalam kurikulum nasional. Pembelajaran bahasa Asing di Indonesia, antara lain bahasa Inggris, Jerman, Prancis, Belanda, Arab, Jepang, Mandarin, dan Rusia. Bahasa Inggris sebagai bahasa asing pertama, diajarkan mulai dari Sekolah Dasar (SD) sampai tingkat pertama di lembagalembaga pendidikan tinggi, bahasa Prancis dan bahasa Arab maupun bahasa Jerman diajarkan di sekolah lanjutan tingkat atas dan lembaga pendidikan tinggi yang mempunyai jurusan kedua bahasa asing tersebut, sedangkan bahasa Mandarin, Jepang, Rusia dan Belanda tidak diajarkan di sekolah-sekolah tingkat pertama maupun tingkat atas tetapi dapat diberikan pada lembaga-lembaga pendidikan yang menginginkannya. 
Bahasa Jerman menjadi salah satu mata pelajaran di tingkat Sekolah Menengah Atas (SMA) dan Madrasah Aliyah (MA). Mata pelajaran Bahasa Jerman diajarkan sejak kelas X hingga kelas XII pada semua jurusan, sehingga diharapkan para siswa lulusan SMA telah mempunyai dasar untuk belajar mendalami bahasa Jerman pada perguruan tinggi bahkan dapat berkomunikasi dengan menggunakan bahasa tersebut. Hanya saja dari hasil observasi dan interview pada bulan Februari dengan guru Bahasa Jerman di SMAN 13 Medan diperoleh informasi bahwa sebagian siswa beranggapan mata pelajaran Bahasa Jerman adalah mata pelajaran yang sulit disebabkan pelajaran tersebut tergolong baru sehingga sering terkontaminasi dengan pelajaran bahasa Inggris dan sebagian siswa lainnya khususnya siswa yang sudah duduk di Kelas XII berpendapat bahwa mata pelajaran Bahasa Jerman tidak penting dibandingkan dengan mata pelajaran lainnya karena mereka dituntut lebih fokus pada mata pelajaran yang diujikan pada Ujian Nasional (UN).Namun pada beberapa orang siswa yang lebih memiliki minat dan motivasi mempelajari Bahasa Jerman adalah siswa yang ingin melanjutkan studi ke Perguruan Tinggi pada jurusan Bahasa Asing.

Dalam mengatasi berbagai permasalahan dalam pembelajaran bahasa Jerman tersebut, maka dapat dilakukan beberapa alternatif pemecahan, diantaranya dengan melakukan inovasi yang dapat meningkatkan motivasi siswa diantaranya : (1) pembelajaran kontekstual (Contextual Teaching Learning), (2) pembelajaran yang menyenangkan (Quantum Teaching), (3) penataan lingkungan belajar (pengelolaan), (4) pembelajaran dengan memanfaatkan multi kecerdasan, dan (5) pendekatan pembelajaran kooperatif. Maka dari beberapa inovasi pembelajaran yang dapat dilakukan peneliti ingin menerapkan pendekatan pembelajaran kooperatif. Model pembelajaran kooperatif dikatakan juga sebagai model pembelajaran kelompok. Model pembelajaran kooperatif yang ingin diterapkan peneliti dalam pembelajaran bahasa Jerman ini adalah tipe Jigsaw. Secara konseptualnya pembelajaran menggunakan model ini mewajibkan siswa untuk belajar dalam kelompok, dimana setiap anggota kelompok akan bekerja sama untuk mencapai tujuan bersama.

\section{Model Pembelajaran Kooperatif Tipe Jigsaw}

Pembelajaran kooperatif disebut juga dengan pembelajaran kelompok. Pembelajaran kelompok adalah rangkaian kegiatan belajar yang dilakukan oleh siswa dalam kelompokkelompok tertentu untuk mencapai tujuan pembelajaran yang telah dirumuskan (Sanjaya, 2009). Ada empat unsur penting dalam pembelajaran kooperatif, yaitu (1) adanya peserta dalam kelompok, (2) adanya aturan kelompok, (3) adanya upaya belajar setiap anggota kelompok, (4) adanya tujuan yang harus dicapai.

Dalam model pembelajaran kooperatif pesertanya adalah siswa yang melakukan proses pembelajaran dalam setiap kelompok belajar. Pengelompokkan siswa bisa ditetapkan berdasarkan beberapa pendekatan, diantaranya pengelompokkan yang didasarkan atas minat dan bakat siswa, pengelompokkan yang didasarkan atas campuran yang ditinjau dari minat maupun campuran ditinjau dari kemampuan. Pendekatan apapun yang digunakan, tujuan pembelajaran haruslah menjadi pertimbangan utama.

Dari alasan yang dikemukakan tersebut, maka pembelajaran kooperatif merupakan bentuk pembelajaran yang dapat memperbaiki sistem pembelajaran yang selama ini memiliki kelemahan. Menurut Sanjaya (2009) bahwa model pembelajaran kooperatif mempunyai dua komponen utama yaitu : (1) komponen tugas kooperatif (cooperative task), (2) komponen struktur insentif kooperatif (cooperativeincentive structure). Dari komponen-komponen tersebut, menguatkan bahwa model pembelajaran kooperatif tepat untuk digunakan sebagai alat ukur dalam meningkatkan hasil belajar siswa, khususnya dengan cara belajar tugas kooperatif.

\section{Model Pembelajaran Langsung (Direct atau Directive Instruction)}

Direct Instruction atau directive instruction, dibahasa-Indonesiakan menjadi pembelajaran langsung, digunakan oleh para peneliti untuk merujuk pada pola-pola pembelajaran dimana guru banyak menjelaskan konsep atau keterampilan kepada sejumlah kelompok siswa dan menguji keterampilan siswa melalui latihan-latihan di bawah bimbingan dan arahan guru. Dengan demikian, tujuan pembelajaran distrukturkan oleh guru.

Sementara itu, direct instruction merujuk pada berbagai teknik pembelajaran ekspositori 
(pemindahan pengetahuan dari guru kepada murid secara langsung, misalnya melalui ceramah, demonstrasi, dan tanya jawab) yang melibatkan seluruh kelas. Pendekatan dalam model pembelajaran ini berpusat pada guru dimana guru menyampaikan isi akademik dalam format yang sangat terstruktur, mengarahkan para siswa, dan mempertahankan fokus pencapaian akademik.

Tujuan utama pembelajaran langsung ini adalah untuk memaksimalkan penggunaan waktu belajar siswa. Beberapa temuan dalam teori perilaku di antaranya adalah pencapaian siswa yang dihubungkan oleh siswa dalam belajar atau tugas dan kecepatan siswa untuk berhasil dalam mengerjakan tugas yang positif. Dengan demikian, model pembelajaran langsung dirancang untuk menciptakan lingkungan belajar terstruktur dan berorientasi pada pencapaian akademik. Guru berperan sebagai penyampai informasi, dalam melakukan tugasnya, guru dapat menggunakan berbagai media, misalnya film, tape recorder, gambar, peragaan. Informasi yang dapat disampaikan dengan strategi direktif dapat berupa pengetahuan prosedural, yaitu pengetahuan tentang bagaimana melakasanakan sesuatu atau pengetahuan deklaratif, yaitu pengetahuan tentang sesuatu dapat berupa pengetahuan tentang sesuatu fakta, konsep, prinsip, atau generalisasi. Pembelajaran langsung dapat didefenisikan sebagai model pembelajaran di mana guru mentransformasikan informasi atau keterampilan secara langsung kepada siswa dan pembelajaran berorientasi pada tujuan dan distrukturkan oleh guru.

Salah satu karakteristik dari suatu model pembelajaran adalah adanya sintaks ataupun tahapan pembelajaran. Di samping harus memperhatikan sintaks, guru yang akan menggunakan model pembelajaran langsung juga harus memperhatikan variable-variabel lingkungan lainnya, yaitu fokus akademik, arahan dan kontrol guru, harapan yang tinggi untuk kemajuan siswa, waktu dan dampak netral dari pembelajaran.

Fokus akademik diartikan sebagai prioritas pemilihan tugas-tugas yang harus dilakukan siswa, selama pembelajaran, aktivitas akademik harus ditekankan. Pengarahan dan kontrol guru terjadi ketika guru memilih tugastugas siswa dan melaksanakan pembelajaran, menentukan kelompok, berperan sebagai sumber belajar selama pembelajaran, dan meminimalisasikan kegiatan non akademik di antara siswa. Kegiatan pembelajaran diarahkan pada pencapaian tujuan sehingga guru memiliki harapan yang tinggi terhadap tugas-tugas yang harus dilaksanakan oleh siswa.Dengan demikian pembelajaran langsung sangat mengoptimalkan penggunaan waktu.

\section{Hakikat Gaya Berpikir Sekuensial}

Dalam proses pembelajaran melatih siswa berpikir merupakan tujuan belajar yang sangat penting. Ketika seseorang membayangkan sesuatu atau berusaha memecahkan persoalan atau masalah, maka kegiatan ini disebut berpikir. Berpikir diperlukan dalam membuat keputusan dan memecahkan masalah. Menurut Ahmadi (2000) berpikir adalah aktivitas psikis yang intensional yang terjadi apabila seseorang menjumpai problema (masalah) yang harus dipecahkan. Gaya berpikir memungkinkan seseorang memiliki keragaman, keunikan yang berbeda dengan orang lain dengan menggunakan informasi yang diterimanya dan cara mengolahnya sebagai alat untuk mempertimbangkan dan mengambil keputusan. Berpikir sebagai keterampilan mental yang memadukan kecerdasan dengan pengalaman. Keterampilan berpikir menentukan bagaimana kecerdasan yang digunakan. Berpikir merupakan kegiatan untuk menemukan pengetahuan yang benar dengan menggunakan proses berpikir dalam menarik suatu kesimpulan yang berupa pengetahuan. Suryabrata (2010) menyatakan bahwa berpikir adalah meletakkan bagian pengetahuan yang diperoleh manusia. Pengetahuan yang dimaksud mencakup konsep, gagasan, dan pengertian yang dimiliki atau diperinci. Menurut Dryden dan Vos (2002) kemampuan manusia berpikir dikarenakan berfungsinya otak sebagai organ luar biasa yang terdiri dari triliun sel-sel yang saling bertukar informasi sehingga memungkinkan manusia untuk bertindak sesuai dengan pikirannya.

Menurut DePorter dan Hernacki (2000) gaya berpikir adalah cara mengingat dan memperhatikan detail dengan mudah dan mengingat fakta-fakta, informasi spesifik, rumus-rumus dan berbagai peraturan dengan mudah. Sementara Tellier dalam DePorter dan Hernacki (2000) mengatakan bahwa gaya berpikir adalah cara yang konsisten yang dilakukan individu dalam mencari informasi, cara mengingat serta memikirkan cara penyelesaian suatu persoalan. 
Dari pendapat di atas, maka dapat disimpulkan bahwa gaya berpikir adalah persepsi individu berkaitan dengan pengetahuan yang diperoleh individu dan cara mengatur dan mereproduksi berbagai informasi yang diperoleh sehingga menimbulkan karakteristik perilaku tersendiri pada individu yang digunakan untuk memecahkan suatu permasalahan. DePorter dan Hernacki (2000), mengungkapkan bahwa ada delapan aspek yang dinilai untuk gaya berpikir, yaitu: 1) cara menyelesaikan suatu persoalan, 2) pola pikir yang dimiliki, 3) aktivitas yang disukai, 4) sikap terhadap lingkungan sekitar, 5) cara atau modal kerja, 6) model berpikir, dan 7) sikap dalam menghadapi persoalan, dan 8) cara belajar yang disukai.

DePorter dan Hernacki (2000) menyatakan bahwa gaya berpikir sekuensial dalam proses berpikirnya bersifat logis, teratur, linier dan rasional. Cara berpikirnya sesuai untuk tugas-tugas teratur, ekpresi verbal, menulis, membaca, menghitung, assosiasi, audiotorial, menempatkan detail dan fakta, fonetik, serta simbolik. Gunawan (2004) menyatakan bahwa pemikir sekuensial mempunyai cara belajar yang khusus, yaitu : 1) menyukai hal-hal yang berurutan, 2) belajar maksimal dari hal-hal yang bersifat detail dulu baru kemudian ke hal-hal yangbersifat global, 3) menyukai sistem membaca yang berdasarkan pada fonetik, 4) menyukai kata-kata, simbol dan huruf, 5) menyukai sesuatu yang berstruktur dan dapat diprediksi, 6) mengalami banyak fokus internal, dan 7) ingin mengumpulkan informasi yang faktual.

\section{Gaya Berpikir Sekuensial Abstrak}

Seseorang yang memiliki gaya berpikir sekuensial abstrak sangat menyukai dunia teori dan pikiran abstrak. Mereka suka berpikir konseptual dan menganalisis informasi. Gaya berpikir sekuensial abstrak bertipe pemikiran abstrak, berpikir konseptual dan menganalisis informasi. Tipe ini biasanya tidak mau menerima begitu saja segala informasi tanpa melakukan cek dan ricek. Mereka yang memiliki gaya berpikir sekuensial abstrak umumnya senang dengan dunia teori, segala sesuatu dihubungkan dengan teori yang mereka baca. Gaya berpikir sekuensial abstrak berpikir dalam sebuah konsep dan analisis informasi. Proses berpikir yang mereka miliki adalah logis, rasional, dan intelektual (DePorter dan Hernacki, 2000).
Seseorang yang memiliki gaya berpikir sekuensial abstrak lebih cenderung menggunakan otak sebelah kanan lebih dominan daripada otak sebelah kiri. Otak kanan lebih bersifat kreatif, biasanya memainkan peranan dengan hal-hal yang berhubungan dengan irama, musik, gambar, dan imajinasi. Proses berpikir otak kanan lebih bersifat acak, tidak teratur, intuitif, dan holistik. Cara berpikirnya sesuai dengan cara-cara untuk mengetahui hal yang bersifat nonverbal, seperti perasaan, emosi, kesadaran yang berkenaan dengan perasaan (merasakan kehadiran benda atau orang), kesadaran spasial, pengenalan bentuk dan pola, musik, seni, kepekaan warna, kreativitas, dan visualisasi (DePorter dan Hernacki, 2000).

\section{Gaya Berpikir Sekuensial Konkrit}

Tipe pemikir pada orang yang memiliki gaya berpikir sekuensial konkrit adalah berpikir realistis dan rasional berdasarkan perolehan yang mereka ketahui melalui indera fisik, baik indera penglihatan, peraba, pendengaran, perasa, maupun penciuman. Bila dikaitkan dengan dua fungsi belahan otak, maka otak kirilah yang mengatur pikiran secararealistis dan rasional, dengan kata lain orang yang memiliki gaya berpikir sekuensial konkrit cenderung menggunakan otak sebelah kiri lebih dominan dari sebelah kanan. Proses berpikir otak kiri bersifat logis, sekuensial, linier, dan rasional (DePorter dan Hernacki, 2000). Otak kiri lebih bersifat akademis dan memainkan peranan dalam pemerosesan logika, kata-kata, matematika, dan urutan.Otak kiri berpikir secara sekuensial, teratur, logis, dan runtut. Kerja otak kiri adalah keteraturan, kerapian, dan sesuatu yang pasti. Dengan demikian orang yang memiliki gaya sekuensial konkrit selalu memperhatikan dan mengingat realitas dengan mudah dan mengingat fakta-fakta, informasi, rumus-rumus, dan aturan-aturan khusus dengan mudah.

Berdasarkan karakteristik yang dimiliki, seseorang dengan gaya berpikir sekuensial konkrit adalah orang yang cenderung teratur dan rapi, biasanya selalu mempunyai catatan yang rapi, selalu tepat waktu, terencana, dan tidak suka hal-hal yang bersifat mendadak. Siswa yang memiliki gaya berpikir sekuensial konkrit biasanya menyenangi kerapian rambut, pakaian, buku dan alat tulis yang tertata dengan baik, bahkan mereka umumnya merasa terganggu jika melihat teman-temannya yang 
tidak rapi berpakaian atau meletakkan sesuatu benda yang tidak teratur. Dalam pembelajaran, kegiatan praktik adalah cara belajar yang terbaik bagi orang yang memiliki gaya berpikir sekuensial konkrit (Dryden dan Vos, 2002). Untuk belajar, catatan dan makalah merupakan cara terbaik yang dapat digunakan. Siswa dengan tipe ini harus mampu mengatur tugastugas menjadi proses tahap demi tahap dan berusaha keras untuk mendapatkan kesempurnaan pada tiap-tiap tahap. Tipe siswa ini juga menyukai pengarahan dan proses kerja khusus.

Berdasarkan uraian latar belakang masalah dan pembatasan masalah di atas, perumusan masalah sebagai berikut :

1. Apakah hasil belajar Bahasa Jerman siswa yang diajarkan dengan menggunakan model pembelajaran kooperatif tipe Jigsaw lebih tinggi dibandingkan dengan hasil belajar Bahasa Jerman siswa yang diajarkan dengan menggunakan model pembelajaran Langsung?

2. Apakah hasil belajar Bahasa Jerman siswa yang memiliki gaya berpikir sekuensial abstrak lebih tinggi dibandingkan hasil belajar Bahasa Jerman siswa yang memilikigaya berpikir sekuensial konkrit?

3. Apakah ada interaksi antara model pembelajaran dengan gaya berpikir sekuensial dalam mempengaruhi hasil belajar Bahasa Jerman?

\section{METODE}

Penelitian ini dilaksanakan di SMAN 13 Medan. Waktu penelitian dilakukan pada semester genap. Populasi dalam penelitian ini adalah seluruh siswa semester genap kelas $\mathrm{X}$. Teknik pengambilan sampel dalam penelitian ini adalah teknik sampel kelompok secara acak (cluster random sampling), yaitu dari tujuh kelas dipilih dua kelas sebagai sampel yang dikenakan perlakuan secara undi. Tahapan dalam melakukan proses penarikan sampel dilakukan dengan menempuh langkah-langkah sebagai berikut

(1). Menuliskan nama seluruh kelas pada lembar kertas kecil, masing-masing satu lembar kertas untuk satu kelas.

(2). Memasukkan lembaran/gulungan kertas kecil tersebut dalam kotak untuk diundi.

(3). Mencabut dua lembar kertas undian, setelah dipilih dua kelas, dua kertas undian itu dimasukkan lagi ke dalam kotak lain kemudian dilakukan pengundian. Hasil pengundian diperoleh kelas X-2 (40 orang) yang diberikan dengan menggunakan model pembelajaran kooperatif tipe Jigsaw dan kelas X-6 (40 orang) yang diberikan dengan menggunakan model pembelajaran Langsung.

Metode Penelitian yang digunakan adalah quasy experiment atau eksperimen semu. Metode ini digunakan karena kelas yang diperlakukan adalah kelas yang sudah terbentuk sebelumnya tanpa mengubah situasi dan kondisi kelas yang sudah terbentuk. Melalui disain ini akan dibandingkan pengaruh model pembelajaran kooperatif tipe Jigsaw dan model pembelajaran Langsung. Model pembelajaran koopeeratif tipe Jigsaw dan model pembelajaran Langsung diperlakukan kepada kelompok eksperimen siswa yang memiliki gaya berpikir sekuensial abstrak dan gaya berpikir sekuensial konkrit berdasarkan hasil analisisis skor tes gaya berpikir yang diadaptasi oleh DePorter yang telah distandarisasi dan disusun dengan menggunakan indikatorindikator yang telah standar karena telah diujicobakan oleh Jhon le teller seorang konsultan di Super Camp, dan peneliti juga menggunakan jasa psikolog. Tes gaya berpikir ini disusun dalam bentuk 15 kelompok kata yang masing-masing kelompok terdiri dari 4 kata. Sampel penelitian dapat memilih 2 diantara 4 kata yang diberikan yang mewakili karakter masing-masing sampel.

Guru yang ditetapkan untuk melakukan pembelajaran dengan model pembelajaran kooperatif tipe Jigsaw maupun Langsung diberikan petunjuk khusus mengenai cara dan langkah-langkah dalam penyajian materi pelajaran. Model pembelajaran kooperatif tipe Jigsaw dan model pembelajaran Langsung sebagai variabel bebas. Gaya berpikir sebagai variabel moderator dan hasil belajar bahasa Jerman sebagai variabel terikat. Variabelvariabel tersebut selanjutnya akan ditinjau dalam penelitian dengan disain pada Tabel Faktorial 2x2.

Tabel 1. Desain Faktorial 2 x 2

\begin{tabular}{ccc} 
Gaya Belajar & \multicolumn{2}{c}{ Model Pembelajaran $(\mathbf{A})$} \\
\cline { 2 - 3 }$(\mathbf{B})$ & Jigsaw $\left(\mathrm{A}_{1}\right)$ & Langsung $\left(\mathrm{A}_{2}\right)$ \\
\hline $\begin{array}{c}\text { Sekuensial } \\
\text { Abstrak }\left(\mathbf{B}_{1}\right)\end{array}$ & $\mathrm{A}_{1} \mathrm{~B}_{1}$ & $\mathrm{~A}_{2} \mathrm{~B}_{1}$ \\
\hline $\begin{array}{c}\text { Sekuensial } \\
\text { Konkrit }\left(\mathbf{B}_{2}\right)\end{array}$ & $\mathrm{A}_{1} \mathrm{~B}_{2}$ & $\mathrm{~A}_{2} \mathrm{~B}_{2}$ \\
\hline
\end{tabular}

Keterangan :

$\mathrm{A}=$ Model Pembelajaran 
$\mathrm{B}=$ Gaya Berpikir

$\mathrm{A}_{1}=$ Model Pembelajaran Tipe Jigsaw

$\mathrm{A}_{2}=$ Model Pembelajaran Langsung

$\mathrm{B}_{1}=$ Gaya Berpikir Sekuensial Abstrak

$\mathrm{B}_{2}=$ Gaya Berpikir Sekuensial Konkrit

$\mathrm{A}_{1} \mathrm{~B}_{1}=$ Hasil belajar bahasa Jerman siswa yang diajar dengan model pembelajaran kooperatif tipe jigsaw yang memiliki gaya berpikir sekuensial Abstrak

$\mathrm{A}_{1} \mathrm{~B}_{2}=$ Hasil belajar bahasa Jerman siswa yang diajar dengan model pembelajaran kooperatif tipe jigsaw yang memiliki gaya berpikir sekuensial Konkrit

$\mathrm{A}_{2} \mathrm{~B}_{1}=$ Hasil belajar bahasa Jerman siswa yang diajar dengan model pembelajaran langsung yang memiliki gaya berpikir sekuensial Abstrak

$\mathrm{A}_{2} \mathrm{~B}_{2}=$ Hasil belajar bahasa Jerman siswa yang diajar dengan model pembelajaran langsung yang memiliki gaya berpikir sekuensial Konkrit

Teknik analisis data yang digunakan adalah teknik statistik deskriptif dan inferesial. Teknik statistik deskriptif digunakan untuk mendeskripsikan data penelitian dengan daftar distribusi frekuensi dan membuat histogram kemudian dihitung mean, median, modus, dan standard deviasinya. Teknik statistik inferesial digunakan untuk menguji hipotesis penelitian dengan teknik ANAVA dua jalur dengan desain faktorial $2 \times 2$ dan taraf signifikansi 0,05. Jika hasil pengujian menunjukan terdapatnya interaksi maka perlu dilakukan uji lanjut. Dalam penggunaan ANAVA dua jalur memenuhi syarat sebagai berikut: (1) data yang digunakan berdistribusi normal, sehingga perlu dilakukan uji normalitas dengan menggunakan uji Lilifors, (2) data harus memilki varians populasi homogen, sehingga dilakukan uji homongenitas varians dengan menggunakan uji Fisher dan Uji Bartlet. Berikut ini adalah hipotesis statistik yang digunakan:

Keterangan :

a. Hipotesis Pertama

$\mathrm{H}_{\mathrm{o}}: \mu \mathrm{A}_{1}=\mu \mathrm{A}_{2}$

$\mathrm{H}_{1}: \mu \mathrm{A}_{1}>\mu \mathrm{A}_{2}$

b. Hipotesis Kedua

$\mathrm{H}_{\mathrm{o}}: \mu \mathrm{B}_{1}=\mu \mathrm{B}_{2}$

$\mathrm{H}_{1}: \mu \mathrm{B}_{1}>\mu \mathrm{B}_{2}$

c. Hipotesis Ketiga

$\mathrm{H}_{0}: \mathrm{A}><\mathrm{B}=0$

$\mathrm{H}_{1}: \mathrm{A}><\mathrm{B} \neq 0$

\section{HASIL PENELITIAN}

Pengujian hipotesis dilakukan menggunakan teknik analisis varians (ANAVA). Untuk keperluaan analisis varians, data yang diperlukan dapat dilihat pada tabel 2 .

Tabel 2. Data Hasil Belajar Bahasa Jerman Siswa

\begin{tabular}{|c|c|c|c|c|c|c|c|}
\hline \multicolumn{2}{|c|}{ Variabel } & \multicolumn{4}{|c|}{ Model Pembelajaran } & \multicolumn{2}{|r|}{ Total } \\
\hline & & & Jigsaw & & angsung & & \\
\hline \multirow{10}{*}{ 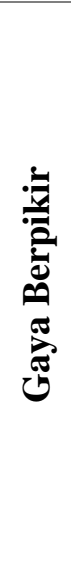 } & \multirow{5}{*}{$\begin{array}{l}\frac{\text { त्ञ }}{\tilde{W}} \\
\text { है }\end{array}$} & $\mathrm{n}$ & $: 24$ & $\mathrm{n}$ & $: 21$ & $\mathrm{n}$ & $: 45$ \\
\hline & & Xrat & : 79,92 & Xrat & $: \quad 52,40$ & Xrat & $: \quad 67,40$ \\
\hline & & $\sum \mathrm{X}$ & : 1915 & $\sum \mathrm{X}$ & : 1120 & $\sum \mathrm{X}$ & $: 3035$ \\
\hline & & $\sum X^{2}$ & : 154503 & $\sum X^{2}$ & : 62892 & $\sum X^{2}$ & : 217395 \\
\hline & & S & $: \quad 8,74$ & $S$ & $: \quad 12,62$ & S & $: \quad 11,40$ \\
\hline & \multirow{5}{*}{ 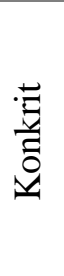 } & $\mathrm{n}$ & $: 16$ & $\mathrm{n}$ & $: 19$ & $\mathrm{n}$ & $: 35$ \\
\hline & & Xrat & $: \quad 57,88$ & Xrat & $: \quad 62,84$ & Xrat & $: \quad 60,40$ \\
\hline & & $\sum X$ & : 928 & $\sum X$ & : 1194 & $\sum \mathrm{X}$ & : 2122 \\
\hline & & $\sum X^{2}$ & : 55274 & $\sum X^{2}$ & : 76106 & $\sum X^{2}$ & : 131380 \\
\hline & & $\mathrm{S}$ & $: 9,86$ & $\mathrm{~S}$ & $: 8,03$ & $\mathrm{~S}$ & $: 9,00$ \\
\hline \multirow{5}{*}{\multicolumn{2}{|c|}{ Total }} & $\mathrm{n}$ & $: 40$ & $\mathrm{n}$ & : 40 & $\mathrm{n}$ & : 80 \\
\hline & & Xrat & $: 70,90$ & Xrat & $: \quad 57,70$ & Xrat & $: 64,3$ \\
\hline & & $\sum X$ & : 2843 & $\sum \mathrm{X}$ & : 2314 & $\sum \mathrm{X}$ & : 5157 \\
\hline & & $\sum X^{2}$ & : 209777 & $\sum X^{2}$ & : 138998 & $\sum X^{2}$ & $: 348775$ \\
\hline & & $\mathrm{S}$ & $: \quad 14,37$ & S & $: 11,85$ & $\mathrm{~S}$ & : 13,10935 \\
\hline
\end{tabular}


Hasil perhitungan ANAVA seperti yang ditunjukkan dalam table 3, yaitu rangkuman analisis faktorial $2 \times 2$.

Tabel 3. Rangkuman Analisis Faktorial 2x2

\begin{tabular}{|c|c|c|c|c|c|}
\hline Sumber variasi & dk & JK & RJK & $\mathbf{F}_{\text {hitung }}$ & $F_{\text {tabel }}(\alpha=0,05)$ \\
\hline Model Pembelajaran & 1 & 3498,013 & 3498,013 & 36,00752 & 3,96 \\
\hline Gaya Berpikir & 1 & 914,605 & 914,605 & 9,414676 & \\
\hline Interaksi & 76 & 4546,119 & 4546,119 & 46,79642 & \\
\hline Galat & 1 & 7383,151 & 97,14673 & & \\
\hline Total & 79 & & & & \\
\hline
\end{tabular}

Berdasarkan rangkuman di atas maka akan dirinci pengujian hipotesis sebagai berikut:

\section{Hipotesis Pertama}

Pengujian hipotesis pertama yang menyatakan: hasil belajar Bahasa Jerman siswa yang dibelajarkan dengan model pembelajaran Kooperatif Tipe Jigsaw lebih tinggi daripada hasil belajar siswa yang diajarkan dengan model pembelajaran Langsung. Hipotesis statistiknya adalah:

$$
\begin{aligned}
& \mathrm{H}_{\mathrm{o}}: \mu \mathrm{A}_{1}=\mu \mathrm{A}_{2} \\
& \mathrm{H}_{1}: \mu \mathrm{A}_{1}>\mu \mathrm{A}_{2}
\end{aligned}
$$

Berdasarkan perhitungan ANAVA faktorial $2 \times 2$ diperoleh $\mathrm{F}_{\text {hitung }}=36,00$ sedangkan nilai $\mathrm{F}_{\text {tabel }}=3,96$ untuk dk $(1,76)$ dan taraf nyata $\alpha=0,05$. Ternyata nilai $F_{\text {hitung }}=36,00>F_{\text {tabel }}$ sehingga pengujian hipotesis menolak Ho. Dengan demikian dapat ditarik kesimpulan bahwa hasil belajar Bahasa Jerman siswa yang dibelajarkan dengan model pembelajaran Kooperatif Tipe Jigsaw lebih tinggi dibanding dengan model pembelajaran Langsung dapat diterima dan terbukti secara empirik. Hal ini juga terlihat dari rata-rata hasil belajar Bahasa Jerman yang dibelajarkan dengan model Kooperatif Tipe Jigsaw $(\bar{x}=70,90)$ lebih tinggi dari hasil belajar Bahasa Jerman yang dibelajarkan dengan model pembelajaran Langsung $(\bar{x}=57,70)$.

\section{Hipotesis Kedua}

Pengujian hipotesis yang kedua yaitu: hasil belajar siswa dengan gaya berpikir Sekuensial Abstrak lebih tinggi daripada hasil belajar siswa dengan gaya berpikir Sekuensial Konkrit.Hipotesis statistiknya adalah:

$$
\mathrm{H}_{\mathrm{o}}: \mu \mathrm{B}_{1}=\mu \mathrm{B}_{2}
$$

\section{$\mathrm{H}_{1}: \mu \mathrm{B}_{1}>\mu \mathrm{B}_{2}$}

Berdasarkan perhitungan ANAVA faktorial $2 \times 2$ diperoleh 63 sedangkan nilai $\mathrm{F}_{\text {tabel }}$ $=3,96$ untuk dk $(1,76)$ dan taraf nyata $\alpha=0,05$. Ternyata nilai $F_{\text {hitung }}=9,41>F_{\text {tabel }}$ sehingga pengujian hipotesis menolak Ho. Dengan demikian dapat ditarik kesimpulan bahwa hasil belajar Bahasa Jerman siswa dengan gaya berpikir Sekuensial Abstrak lebih tinggi daripada hasil belajar Bahasa Jerman siswa dengan gaya berpikir Sekuensial Konkrit dapat diterima dan terbukti secara empirik. Hal ini juga terlihat dari rata-rata hasil belajar Bahasa Jerman siswa dengan gaya berpikir Sekuensial Abstrak ( $\bar{x}=67,40)$ lebih tinggi dari hasil belajar Bahasa Jerman siswa dengan gaya berpikir Sekuensial Konkrit $(\bar{x}=60,40)$.

\section{Hipotesis Ketiga}

Pengujian hipotesis yang ketiga yaitu: terdapat interaksi antara model pembelajaran dan gaya berpikir sekuensial dalam meningkatkan hasil belajar Bahasa Jerman. Hipotesis statistiknya adalah:

$$
\begin{aligned}
& \mathrm{H}_{0}: \mathrm{A}><\mathrm{B}=0 \\
& \mathrm{H}_{1}: \mathrm{A}><\mathrm{B} \neq 0
\end{aligned}
$$

Berdasarkan perhitungan ANAVA faktorial $2 \times 2$ diperoleh $F_{\text {hitung }}=46,79$ sedangkan nilai $\mathrm{F}_{\text {tabel }}=3,96$ untuk dk $(1,76)$ dan taraf nyata $\alpha=0,05$. Ternyata nilai $F_{\text {hitung }}=46,79>3,96=$ $\mathrm{F}_{\text {tabel }}$ sehingga pengujian hipotesis menolak Ho. Dengan demikian dapat ditarik kesimpulan bahwa terdapat interaksi antara model pembelajaran dan gaya berpikir dalam meningkatkan hasil belajar Bahasa Jermansiswa dapat diterima dan terbukti secara empirik.

Untuk mengetahui interaksi antara model pembelajaran dan gaya berpikir terhadap hasil belajar Bahasa Jerman, maka dilakukan uji 
lanjut dengan Uji Scheffe. Perhitungan untuk dilihat pada Tabel 4 berikut : uji Scheffe. Rangkuman uji Scheffe dapat

Tabel.4. Rangkuman Uji Lanjut

\begin{tabular}{cccccc}
\hline No & \multicolumn{2}{c}{ Interaksi } & Fhitung & Ftabel $(\boldsymbol{\alpha}=\mathbf{0 , 0 5})$ & Keterangan \\
\hline $\mathbf{1}$ & $\mu \mathrm{A}_{1} \mathrm{~B}_{1}$ & $\mu \mathrm{A}_{1} \mathrm{~B}_{2}$ & 6,928927 & 2,72 & Signifikan \\
\hline $\mathbf{2}$ & $\mu \mathrm{A}_{1} \mathrm{~B}_{1}$ & $\mu \mathrm{A}_{2} \mathrm{~B}_{1}$ & 9,341478 & 2,72 & Signifikan \\
\hline $\mathbf{3}$ & $\mu \mathrm{A}_{1} \mathrm{~B}_{1}$ & $\mu \mathrm{A}_{2} \mathrm{~B}_{2}$ & 5,641358 & 2,72 & Signifikan \\
\hline $\mathbf{4}$ & $\mu \mathrm{A}_{2} \mathrm{~B}_{2}$ & $\mu \mathrm{A}_{2} \mathrm{~B}_{1}$ & 3,344509 & 2,72 & Signifikan \\
\hline $\mathbf{5}$ & $\mu \mathrm{A}_{2} \mathrm{~B}_{2}$ & $\mu \mathrm{A}_{1} \mathrm{~B}_{2}$ & 1,67248 & 2,72 & tidak signifikan \\
\hline $\mathbf{6}$ & $\mu \mathrm{A}_{2} \mathrm{~B}_{1}$ & $\mu \mathrm{A}_{1} \mathrm{~B}_{2}$ & 1,485224 & 2,72 & tidak signifikan \\
\hline
\end{tabular}

Keterangan:

$\mu_{\mathrm{A} 1 \mathrm{~B} 1}$ : Rata-rata hasil belajar Bahasa Jerman siswa dengan model pembelajaran Kooperatif Tipe Jigsaw dan gaya berpikir sekuensial Abstrak.

$\mu_{\mathrm{A} 1 \mathrm{~B} 2}$ : Rata-rata hasil belajar Bahasa Jerman siswa dengan model pembelajaran Kooperatif Tipe Jigsaw dan gaya berpikir Sekuensial Konkrit.

$\mu_{\mathrm{A} 2 \mathrm{~B} 1}$ : Rata-rata hasil belajar Bahasa Jerman siswa dengan model pembelajaran Langsung dan gaya berpikir sekuensial Abstrak.

$\mu_{\mathrm{A} 2 \mathrm{~B} 2}:$ Rata-rata hasil belajar Bahasa Indonesia siswa dengan model pembelajaran Langsung dan gaya berpikir Sekuensial Konkrit.

Dari hasil uji Scheffe di atas diperoleh simpulan: (1) Rata-rata hasil belajar Bahasa Jerman siswa dengan model pembelajaran Kooperatif Tipe Jigsaw dan gaya berpikir Sekuensial Abstrak lebih tinggi dibandingkan dengan rata-rata hasil gaya berpikir sekuensial Abstrak. (2) Rata-rata hasil belajar Bahasa Jerman siswa dengan model pembelajaran Kooperatif Tipe Jigsaw dan gaya berpikir Sekuensial Abstrak lebih tinggi dibanding dengan rata-rata hasil belajar Bahasa Jerman siswa Konkrit. (3) Rata-rata hasil belajar Bahasa Jerman siswa dengan model pembelajaran Kooperatif Tipe Jigsaw dan gaya berpikir Sekuensial Abstrak lebih tinggi dibandingkan dengan rata-rata hasil belajar Bahasa Jerman siswa dengan model pembelajaran Langsung dan gaya berpikir Sekuensial Konkrit. (4) Rata-rata hasil belajar Bahasa Jerman siswa dengan model pembelajaran Kooperatif Tipe Jigsaw dan gaya berpikir Sekuensial Konkrit lebih tinggi dibanding dengan rata-rata hasil belajar Bahasa Jerman siswa dengan model pembelajaran
Langsung dan gaya berpikir sekuensial Abstrak. (5) Rata-rata hasil belajar Bahasa Jerman siswa dengan model pembelajaran Langsung dan gaya berpikir Sekuensial Abstrak lebih tinggi dibandingkan dengan Rata-rata hasil belajar Bahasa Jerman siswa dengan model pembelajaran Langsung dan gaya berpikir Sekuensial Konkrit. (6) Rata-rata hasil belajar Bahasa Jerman siswa dengan model pembelajaran Langsung dan gaya berpikir Sekuensial Konkrit lebih tinggi dibandingkan dengan rata-rata hasil belajar Bahasa Jerman siswa dengan model pembelajaran Kooperatif Tipe Jigsaw dan gaya berpikir Sekuensial Konkrit.

Hasil pengujian lanjut di atas, menunjukkan adanya interaksi antara model pembelajaran dan gaya berpikir sekuensial terhadap hasil belajar Bahasa Jerman siswa SMAN 13 Medan. Interaksi model pembelajaran dan gaya berpikir dapat ditunjukkan seperti pada gambar berikut:

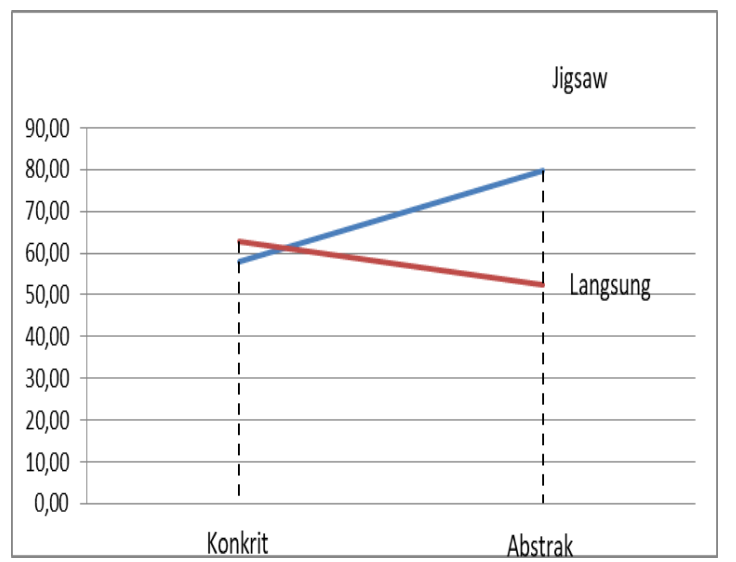

Gambar 1. Interaksi Model Pembelajaran dan Gaya Berpikir Sekuensial

\section{PEMBAHASAN}

1. Hasil belajar Bahasa Jerman siswa yang diajarkan dengan model pembelajaran Kooperatif Tipe Jigsaw lebih tinggi 
daripada hasil belajar siswa yang diajarkan dengan model pembelajaran Langsung

Berdasarkan uraian sebelumnya diketahui secara keseluruhan rata-rata hasil belajar Bahasa Jerman siswa SMAN 13 Medan yang dibelajarkan dengan model pembelajaran Kooperatif Tipe Jigsaw lebih baik daripada rata-rata hasil belajar Bahasa Jerman siswa yang dibelajarkan dengan model pembelajaran Langsung. Hal ini menunjukkan bahwa model pembelajaran Kooperatif Tipe Jigsaw terbukti efektif dapat meningkatkan hasil belajar Bahasa Jerman secara keseluruhan baik untuk kelompok gaya berpikir Sekuensial Abstrak maupun gaya berpikir Sekuensial Konkrit.

Dengan demikian hipotesis pertama yang diajukan yaitu hasil belajar Bahasa Jerman siswa yang dibelajarkan dengan model pembelajaran Kooperatif Tipe Jigsaw lebih tinggi daripada hasil belajar siswa yang diajarkan dengan model pembelajaran Langsung dapatlah diterima. Hasil penelitian ini mendukung teori yang dikemukakan oleh Lie (2004) mengemukakan bahwa siswa tidak hanya mempelajari materi yang diberikan, tetapi mereka juga harus siap memberikan dan mengajarkan materi tersebut pada anggota kelompoknya yang lain. Dengan demikian, siswa saling tergantung satu sama lain dan harus bekerja sama secara kooperatif untuk mempelajari materi yang ditugaskan. Para anggota dari tim-tim yang berbeda dengan topik yang sama bertemu untuk berdiskusi (dinamakan tim ahli) saling membentuk satu sama lain tentang topik pembelajaran yang ditugaskan kepada mereka. Kemudian siswasiswa itu kembali pada tim (kelompok asal) untuk menjelaskan kepada anggota kelompok yang lain tentang apa yang telah mereka pelajari sebelumnya pada pertemuan tim ahli.

Pada model pembelajaran kooperatif tipe Jigsaw, terdapat kelompok asal dan kelompok ahli. Kelompok asal yaitu kelompok induk siswa yang beranggotakan siswa dengan kemampuan, asal, dan latar belakang keluarga yang beragam. Kelompok asal merupakan gabungan dari beberapa ahli. Kelompok ahli yaitu kelompok siswa yang terdiri dari anggota kelompok asal yang berbeda yang ditugaskan untuk mempelajari dan mendalami topik tertentu dan menyelesaikan tugas-tugas yang berhubungan dengan topiknya untuk kemudian dijelaskan kepada anggota kelompok asal.
Dalam model pembelajaran Kooperatif Tipe Jigsaw ini siswa dituntut bertanggung jawab dengan tiap kelompok, maka siswa dapat belajar bertanggung jawab dan lebih memahami batasan yang didiskusikan, siswa menjadi lebih kreatif dan tanggap dalam menemukan penyelesaian soal yang belum mereka mengerti sehingga dengan model Jigsaw ini siswa bisa lebih aktif untuk belajar dan dapat menjalin kerjasama yang baik antara siswa yang lain, sehingga prestasi setiap siswa menjadi meningkat dengan model pembelajaran yang membentuk siswa menjadi lebih aktif dan kreatif dalam proses belajar.

Hal ini sesuai dengan temuan penelitian yang terdahulu yaitu Penelitian yang dilakukan Setyaningsih (1999) menyimpulkan bahwa model pembelajaran kooperatif tipe Jigsaw dapat meningkatkan kualitas pengelolaan proses belajar mengajar oleh guru dan juga dapat meningkatkan kualitas interaksi siswa dengan lingkungan belajar serta meningkatkan prestasi belajar. Dan penelitian yang dilakukan Johannes (2006) membuktikan bahwa pembelajaran kooperatif Jigsaw terbukti efektif dalam pembelajaran sastra bukan hanya pada pembelajaran eksakta.

Pengujian hipotesis yang pertama ini menunjukkan hasil belajar bahasa Jerman yang diajarkan dengan siswa dengan model pembelajan kooperatif tipe Jigsaw lebih tinggi dan efektif dibandingkan dengan model pembelajaran langsung.

2. Hasil belajar Bahasa Jerman Siswa Yang Memiliki gaya berpikir Sekuensial AbstrakLebih Tinggi Daripada hasil belajar Bahasa Jerman Siswa Yang Memiliki Gaya Berpikir Sekuensial Konkrit.

Hasil belajar Bahasa Jerman siswa yang diajarkan dengan model pembelajaran Kooperatif Tipe Jigsaw dan gaya berpikir Sekuensial Abstrak lebih baik hasil belajar siswa dengan gaya berpikir Sekuensial Konkrit. Bila dibandingkan dengan model pembelajaran Langsung, rata-rata hasil belajar Bahasa Jerman siswa dengan gaya berpikir Sekuensial Abstrak maka gaya berpikir Sekuensial Konkrit lebih baik digunakan terhadap hasil belajar Bahasa Jerman siswa. Hal ini menunjukkan bahwa gaya berpikir sekuensial signifikan untuk membedakan hasil belajar Bahasa Jerman siswa, yang hasil belajar Bahasa Jerman dengan gaya berpikir Sekuensial Abstrak lebih baik 
dibelajarkan dengan model pembelajaran Kooperatif Tipe Jigsaw.

Pengujian hipotesis yang kedua ini menunjukkan bahwa hasil belajar Bahasa Jerman dari siswa yang memiliki gaya berpikir Sekuensial Abstrak lebih tinggi daripada hasil belajar Bahasa Jerman dari siswa yang memiliki gaya berpikir Sekuensial Konkrit. Hasil ini membuktikan bahwa gaya berpikir Sekuensial Abstrak signifikan untuk membedakan hasil belajar Bahasa Jerman. Gaya berpikir dalam penelitian ini dibedakan atas gaya berpikir Sekuensial Abstrakdan gaya berpikir Sekuensial Konkrit. Dari hasil analisis data secara keseluruhan diperoleh rata-rata hasil belajar siswa dengan gaya berpikir Sekuensial Abstrak lebih tinggi dari hasil belajar siswa dengan gaya berpikir Sekuensial Konkrit.

Hal ini sesuai dengan temuan penelitian terdahulu yang dilakukan Rahma El Yunusiyah (2010) di SMK Panca Budi bahwa siswa yang memiliki gaya berpikir sekuensial Abstrak yang dibelajarkan dengan strategi pembelajaran yang sama akan memperoleh hasil belajar Kewirausahaan yang lebih tinggi dibandingkan dengan siswa yang memiliki gaya belajar sekuensial Konkrit. Hal ini sesuai dengan pendapat DePorter dan Hernacki, 2003) yang menyatakan bahwa gaya berpikir sekuensial abstrak mereka memiliki pemikiran yang logis, rasional, dan intelektual.

Hipotesis yang kedua berindikasi bahwa siswa yang dengan gaya berpikir Sekuensial Abstrak secara rata-rata mempunyai hasil belajar Bahasa Jerman yang lebih tinggi dibanding siswa dengan gaya berpikir Sekuensial Konkrit. Dengan demikian siswa dengan gaya berpikir Sekuensial Abstrak lebih memahami dan menguasai materi pelajaran Bahasa Jerman dibandingkan siswa dengan gaya berpikir Sekuensial Konkrit.

3. Terdapat Interaksi Antara Model Pembelajaran dan Gaya Berpikir Sekuensial Dalam Mempengaruhi Hasil Belajar Bahasa Jerman Siswa

Pengujian hipotesis yang ketiga terdapat interaksi antara model pembelajaran dan gaya berpikir sekuensial dalam mempengaruhi hasil belajar Bahasa Jerman siswa SMAN 13 Medan. Apabila dilihat dari rata-rata nilai hasil belajar Bahasa Jerman kelompok siswa dengan gaya berpikir Sekuensial Abstrakdan dibelajarkan dengan model pembelajaran Kooperatif Tipe Jigsaw lebih baik dibandingkan dengan rata-rata hasil belajar Bahasa Jerman kelompok siswa dengan gaya berpikir Sekuensial Abstrak yang dibelajarkan dengan model pembelajaran Langsung. Kemudian rata-rata hasil belajar Bahasa Jerman kelompok siswa dengan gaya berpikir Sekuensial Konkrit yang dibelajarkan dengan strategi pembelajaran Langsug lebih tinggi dibandingkan dengan rata-rata hasil belajar Bahasa Jerman kelompok siswa dengan gaya berpikir Sekuensial Konkrit yang dibelajarkan dengan model pembelajaran Kooperatif Tipe Jigsaw .

Hal ini bermakna bahwa bagi kelompok siswa dengan gaya berpikir Sekuensial Konkrit lebih baik menggunakan model pembelajaran Langsung dibandingkan dengan model pembelajaran Kooperatif Tipe Jigsaw, walaupun perbedaannya tidak terlalu signifikan. Dengan demikian dapatlah ditarik kesimpulan bahwa model pembelajaran dan gaya berpikir sekuensial cukup signifikan mempengaruhi hasil belajar Bahasa Jerman siswa.

Semua hipotesis penelitian dapat disimpulkan bahwa: (1) hasil belajar Bahasa Jerman siswa yang dibelajarkan dengan model pembelajaran Kooperatif Tipe Jigsaw lebih tinggi daripada hasil belajar siswa yang dibelajarkan dengan smodel pembelajaran Langsung, (2) hasil belajar siswa dengan gaya berpikir Sekuensial Abstrak lebih tinggi daripada hasil belajar siswa dengan gaya berpikir Sekuensial Konkrit dan (3) terdapat interaksi antara model pembelajaran dan gaya berpikir sekuensial siswa dalam memberikan pengaruh terhadap hasil belajar Bahasa Jerman siswa, ketiga-tiganya dapat diterima.

\section{PENUTUP}

Berdasarkan pengolahan data dan pembahasan terhadap hasil penelitian yang dikemukakan sebelumnya maka dalam penelitian ini dapat disimpulkan bahwa :

1. Hasil belajar Bahasa Jerman siswa yang dibelajarkan dengan menggunakan Model Pembelajaran berbasis Kooperatif Tipe Jigsaw lebih tinggi dari hasil belajar Bahasa Jerman siswa yang dibelajarkan dengan menggunakan Model Pembelajaran Langsung.

2. Hasil belajar Bahasa Jerman siswa yang memiliki gaya berpikir sekuensial Abstrak lebih tinggi daripada hasil belajar Bahasa 
Jerman siswa yang memiliki gaya berpikir sekuensial Konkrit

3. Terdapat interaksi antara penggunaan Model Pembelajaran dan Gaya Berpikir sekuensial dalam mempengaruhi hasil belajar Bahasa Jerman siswa.

\section{DAFTAR PUSTAKA}

Ahmadi, A. (2000). Pengelolaan Pengajaran. Jakarta : Rineka Cipta

Arikunto, S. (2003). Dasar-dasar Evalusi Pendidikan (Ed. Revisi). Jakarta: Bumi Aksara.

Arends, RI, 1997. Learning to Teach. Yogyakarta : Pustaka belajar. 2008. Learning to Teach (terjemahan Soetjipto, H.P). Yogyakarta : Pustaka belajar.

Aufderstrße, Müller, und Storz. (2002). Delfin : Lehwerkfür Deutsch als Fremdsprache, Deutschland : Max Hueber Verlag.

Bigge, M L. (1982). Learning Theories for Teachers. New York : Harper \& Row Publisher.

Bloom, B. (1986). Taxonomy of Educational Objectives. Handbook 1 : Cognitive Domain. New York : David Mc. Kay.

De Porter, B. \& Hernacki, M. (2000). Quantum Learning. Bandung : Penerbit Kaifa.

Dimyati dan Mudjiono. (1999). Belajar dan Pembelajaran. Jakarta : Rineka Cipta.

Djamarah, S. B, dkk.(2010) Strategi Belajar Dan Mengajar. Jakarta : Rineka Cipta.

Gagné, R. M. (1977). The Conditioning of Learning.Third Edition. New York : Holt, Rinehart and Winston.

Gagné, R. M, dan Briggs, L. J, (1979). Principles of Instructional Design. Second Edition. New York : Holt, Rinehart and Winston.

Götz, D, Hänsch, G. und Wellman, H. (2003). Langenscheidt Großwörterbuch Deutsch als Fremdsprache. Berlin und München : Langensheidt, $\mathrm{KG}$.

Gunawan, A, W. 2003. Born to A Genius. Jakarta : Gramedia Pustaka.

Hamalik, O. (2008). Perencanaan Pengajaran Berdasarkan Pendekatan Sistem. Jakarta: Bumi Aksara.

Hamid, A. K. (2007). Teori Belajar dan Pembelajaran. Medan: Pascasarjana Unimed.

Ibrahim, Muslimin. (2000). Pembelajaran Kooperatif. Surabaya : Universitas Negeri Surabaya.
Johannes, P. (2006). Strategi Pembelajaran Kooperatif Tipe Jigsaw Terhadap Hasil Belajar Bahasa Indonesia Pada Siswa Kelas XI SMA Negeri 11 Medan. Tesis : Program Pascasarjana Universitas Negeri Medan.

Joyce, B. \& Weil, M. (1986). Model Of Teaching. New Jersey : Prntice. Hall, inc.

Lie, A. (2004). Cooperative Learning. Jakarta : PT. Gramedia Widiasarana Indonesia.

Miarso. Y. H (2007). Menyemai Benih Teknologi Pendidikan : Mizan Pustaka.

Mulyana, Deddy. (2007). Ilmu Komunikasi. PT Remaja Rosdakaraya : Bandung.

Nelfiza. (2009). Strategi Pembelajaran Inkuiri dan Gaya Berpikir Terhadap Hasil Bahasa Inggris Pada Siswa SMPN 2 Tebing Tinggi. Tesis : Program Pascasarjana Universitas Negeri Medan.

Purwanto, N. M. (2007). Psikologi Pendidikan. Bandung : Remaja Rosdakarya.

Reigeluth, C. M. (1983). Instructional Design Theories and Models: an Overview of their Current Status, Instructional Design: What is it? New Jersey: Publishers Hildshale.

Ruslan. (2006). Pengaruh Model Pembelajaran Berbasis Masalah Dan Kemampuan Berpikir Sekuensial Terhadap Hasil Belajar Kimia. Tesis : Program Pascasarjana Universitas Negeri Medan.

Sagala, S. (2006).Konsep dan Makna Pembelajaran, Bandung: Alfabeta.

Sanjaya, W. (2009). Strategi Pembelajaran Berorientasi Standar Proses Pendidikan. Jakarta : Kencana Prenada Media Group.

Slavin, RE. (1995). Cooperative Learning Theory.Second Edition. Massachussets :Allyn and Bacon Pubher.

Seels, B.B \& Richey. (1994). Intructional Technologi: The Defenition and Domain Of Field. Washington, DC : AECT.

Setyaningsih. (1999). Strategi Pembelajaran Kooperatif Tipe Jigsaw Terhadap Hasil Belajar Biologi Siswa Kelas 1 SLTP Medan. Tesis : Program Pascasarjana Universitas Negeri Medan.

Sudijono, A. (2002). Pengantar Evaluasi Pendidikan, Jakarta : Rajawali Pers.

Sudjana, (2002). Metode Statistika. Bandung :Tarsito.

Sudjana N. dan Rivai A. (2003). Teknologi Pembelajaran. Bandung : Sinar Baru Algensindo. 
Suryabrata, Sumadi. (2002). Psikologi Pendidikan. Jakarta : Raja Grafindo Persada.

Surapranata, S. (2004) Analisis Validitas, Reliabilitas dan Interpretasi Hasil Tes, Bandung: Remaja Rosdakarya.

Walgito, Bimo. (2004). Pengantar Psikologi Umum. Yogyakarta : Andi.
Yunusiyah, El Rahmah. (2010). Pengaruh Strategi Pembelajaran Dan Gaya Berpikir Sekuensial Terhadap Hasil Belajar Kewirausahaan Siswa Panca Budi 2 Medan. Tesis : Program Pascasarjana Universitas Negeri Medan. 